'n Tapisserie met klein diere.

Erika Murray-Theron. 2007. Kaapstad:

Tafelberg. 191 pp. ISBN: 978-0-624-04618-9.

Erika Murray-Theron se nuutste roman was die wenner van 2007 se Insig-romanwedstryd. In die anonieme beoordelingsproses wat dié wedstryd behels, is die beoordelaars vry van die noodwendige verwysingsraamwerk waarmee die leser normaalweg 'n nuwe boek van 'n gevestigde skrywer benader ('n interessante proses om te bestudeer). Miskien was dit ook vir die skryfster 'n unieke geleentheid om ' $n$ ander aanslag uit te toets en te eksperimenteer met ander tegnieke. Die geslaagdheid al dan nie van hierdie "eksperiment" is iets waaroor resensente in die pers verskil het.

In die 2006-film Junebug word 'n greep uit die lewens van ' $n$ gesin uitgebeeld wanneer "die verlore seun" saam met sy vriendin uit die stad op besoek kom. Al wat ons te sien kry, is fragmente van hulle huidige bestaan teen die onmiskenbare agtergrond van die verlede. Bepaalde gebeure vorm die klimaks van die film, maar die narratief eindig nie beslis of opgelos nie. Daar is eerder die bewustheid dat die verhaal van die karakters se lewens nog lank nadat ons ophou kyk het, moet voortgaan, en dat die kyker bloot toevallig 'n stukkie van hierdie verhaal meegemaak het.

' $n$ Tapisserie met klein diere is 'n soortgelyke kompakte kyk op'n aantal dae in 'n familie se lewens. Ook hier kry ons slegs fragmente te sien. Soos die verteller dit op bladsy 5 stel: die outeur bring 'n stel karakters op die verhoog byeen, elkeen losgemaak uit hulle onmiddellike konteks. Hierdie karakters is vir 'n beperkte tyd met ons en daar is heelwat wat ons nooit van hulle te wete kom nie. Tegelykertyd is die roman' $n$ digte samevatting van hulle familiegeskiedenis met allerlei konflikte wat op die spits gedryf word.

Dit is by Gerhardt se strandhuis waar sy niggies Maryn en Juliana, hulle broers Dries- sen en Sias, en hulle moeder, Dorothea, vir Kersfees bymekaar kom. Daar is ook Eben, Gerhardt se pa, en Maryn en Juliana se gesinne. Uiteindelik is daar ook die sterk teenwoordigheid van Laas, Dorothea se man, en Alet, haar dogter, albei oorlede.

Elkeen van die karakters se lewens word op die een of ander wyse geteken deur egte of verbeelde skuld, of hulle nou in die posisie van slagoffer of verantwoordelike staan. Trouens, hierdie onderskeid word as uiters onseker en onstabiel uitgebeeld. Is enigiemand volkome te blameer vir die pyn wat hulle ander aandoen, as hulle self die produk van hulle verledes is, waaraan andere weer aandadig was? Is iemand vooruitbestem om ' $n$ bepaalde paadjie te loop weens die wyse waarop hy deur sy verlede of erflikheid gevorm is? Is daar maniere om vir die foute van die verlede te vergoed, of jouself van die verlede los te maak?

'n Kenmerkende eienskap van die vertelling is die wyse waarop die narratief onderbreek word deur hoofstukke waarin die verteller op "die skrywer" fokus en die skryfproses vanuit hierdie perspektief beskryf (hoofstukke 1, 6, 25, 32 en 36). Aangesien dit 'n kwessie van slegs enkele hoofstukke is, is die ganse narratief nie aan selfrefleksiwiteit onderworpe nie. Die verhaalverloop is lineêr behalwe vir terugflitse. ' $n$ Tapisserie met klein diere as teks dra dus tot 'n beperkte mate die stempel van die postmodernisme, en tog is die postmoderne kondisie 'n noodsaaklike gegewe by die verhaal. Die karakters worstel nie alleenlik met begrippe soos goed en kwaad nie, maar met die einste manier waarop hierdie begrippe gedefinieer word en deur die individu beliggaam word in' $n$ tyd van pluralisme en relatiwiteit. Aan die een kant dekonstrueer die karakters 'n moontlike narratief van erfsonde en determinisme, maar aan die ander kant openbaar hulle worstelinge 'n behoefte daaraan om te glo dat versoening en vergifnis nie ontwykend, ontasbaar en relatief geword het nie. 
Die hoofstukke waarin die teks op homself invou, handel enersyds oor die uitdagings waarmee enige skrywer nog altyd te kampe gehad het, naamlik oor hoeveel ruimte om aan elke karakter af te staan, in watter mate indringing in elke karakter moet plaasvind, watter ruimtes om te selekteer, ensovoorts. Maar van meet af aan is daar ook die tipiese postmoderne verskynsel dat die skrywer deel word van sy eie narratief: "As dit vir'n mens moontlik is om ander ter wille van homself te gebruik, kan jy nie die karakters in jou verhaal ook so misbruik nie? Ter wille van verontskuldiging, ter wille van katarsis, selfs ter wille van ontvlugting of ontkenning en selfbedrog? Waar begin en eindig jou verantwoordelikheid ten opsigte van die mense in jou storie?" (23).

In uitlatings soos dié word die sentrale temas van die roman dus in direkte verband met die skryfproses gebring: karakters wat andere misbruik, karakters wat hul verledes probeer ontvlug of ontken, karakters op soek na katarsis. Vrae oor "aanspreeklikheid en toerekenbaarheid en skuld" (112). Die skrywer is nie dood in hierdie teks nie, maar tegelykertyd word die vernaamste vraagstukke van die roman uiters naby die leser gebring en word die leser al een wat ' $n$ oordeel kan fel. Want in hierdie roman word nie alle vrae beantwoord nie, en die sluiting wat bereik word, is slegs gedeeltelik.

Daar is genoem dat postmodernisme ' $n$ noodsaaklike gegewe by hierdie roman is. Dit is soos die agtergrond van die tapisserie waaroor Dorothea, die wewer, en Gerhardt in hoofstuk 17 praat met "'n vulkaan en klein diertjies" daarop. Die ganse agtergrond van die roman is trouens die vulkaan: die private en kollektiewe geskiedenisse van die karakters wat gewelddadig en pynlik en soms spektakulêr was en is. Die roman bestaan egter deels uit die vulkaan maar ook veral uit die "klein diere" wat met aandag en liefde geborduur is. 'n Tapisserie met klein diere lees so maklik en vlot dat die leser byna onverhoeds deur die einde van die roman betrap word. Dan moet daar bestekopname gedoen word van die indruk wat die verhaal op hom of haar gelaat het. Só is die lewe immers ook dikwels: ons word nie noodwendig die kans gegun om stil te staan by gebeure nie en word deur'n meëdoenlose stroom van tyd en ervarings meegesleur waaroor ons pas veel later kan besin. Dit is ten seerste waar van die karakters in hierdie roman. Die besonderse eienskap van die leeservaring is die feit dat die leser kan terugblaai, herlees en stadig maar seker'n eie weefwerk - die integrasie van die roman se kern in homself - tot stand kan bring. By ' $n$ Tapisserie met klein diere is hierdie proses ' $n$ belonende een.

Jacomien van Niekerk

Universiteit van Pretoria, Pretoria

\section{Die son kom aan die seekant op.}

Jeanette Ferreira. Kaapstad:

Human \& Rousseau. 2007. 222 pp.

ISBN: 978-0-7981-4882-5.

Die verskyning van Jeanette Ferreira se Die son kom aan die seekant op is 'n waardevolle bydrae tot die genre van die historiese roman in Afrikaans.

Die roman het sy ontstaan in die outeur se kennismaking met die kladboek/dagboek van L. Tregardt/Trigardt, Trigard, Tregaardt.

"Op die oorspronklike Sweedse Trädgardt: tuin, herroep sy ..."

Ferreira moes die dagboek bestudeer as deel van haar honneurstudie in taalkunde. Vir hierdie doel het sy J. H. le Roux se 1966-uitgawe van die dagboek gebruik. Met die skryf van die roman was Gustav Preller se 1938uitgawe, Dagboek van Louis Trichardt (18361838), ook deel van die uitgebreide bronne- 